\title{
Thermostable gel polymer electrolyte based on succinonitrile and ionic liquid for high-performance solid-state supercapacitors
}

\author{
Gaind P. Pandey ${ }^{\mathrm{a}}$, Tao Liu ${ }^{\mathrm{a}}$, Cody Hancock ${ }^{\mathrm{a}, \mathrm{b}}$,Yonghui Li ${ }^{\mathrm{c}}$, Xiuzhi Susan Sun ${ }^{\mathrm{c}}$ and Jun Li ${ }^{\mathrm{a}}{ }^{*}$ \\ ${ }^{a}$ Department of Chemistry, Kansas State University, Manhattan, KS 66506, USA \\ ${ }^{b}$ Department of Chemical and Biological Engineering, Iowa State University, Ames, Iowa 50011, \\ USA \\ ${ }^{c}$ Department of Grain Science and Industry, Biomaterials and Technology Lab, Kansas State \\ University, Manhattan, KS 66502, USA
}

Abstract

A flexible, free-standing, thermostable gel polymer electrolyte based on plastic crystalline succinonitrile (SN) and ionic liquid 1-butyl-3-methylimidazolium tetrafluoroborate $\left(\mathrm{BMImBF}_{4}\right)$ entrapped in copolymer poly(vinylidene fluoride-co-hexafluoropropylene) (PVdFHFP) is prepared and optimized for application in solvent-free solid-state supercapacitors. The synthesized gel polymer electrolyte exhibits a high ionic conductivity over a wide temperature range (from $\sim 5 \times 10^{-4} \mathrm{~S} \mathrm{~cm}^{-1}$ at $-30{ }^{\circ} \mathrm{C}$ up to $\sim 1.5 \times 10^{-2} \mathrm{~S} \mathrm{~cm}^{-1}$ at $80{ }^{\circ} \mathrm{C}$ ) with good electrochemical stability window (-2.9 to $2.5 \mathrm{~V})$. Thermal studies confirm that the SN containing gel polymer electrolyte remains stable inthe same gel phase over a wide temperature rangefrom 30 to $90{ }^{\circ} \mathrm{C}$. The electric double layer capacitors (EDLCs) have been fabricated using activated carbon as active materials and new gel polymer electrolytes. Electrochemical performance of the EDLCs is assessed through cyclic voltammetry, galvanostatic charge-discharge cycling and impedance spectroscopy. The EDLC using SN containing gel polymer electrolyte has been found to give highspecific capacitance $176 \mathrm{~F} \mathrm{~g}^{-1}$ at $0.18 \mathrm{~A} \mathrm{~g}^{-1}$ and $138 \mathrm{~F} \mathrm{~g}^{-1}$ at $8 \mathrm{~A} \mathrm{~g}^{-1}$ constant current density. The EDLC cell with SN containing gel electrolyte shows good cycling stability and retains $\sim 80 \%$ of the initial capacitance after 10,000 cycles.

Keywords: Supercapacitors; ionic liquid; gel polymer electrolyte, succinonitrile, solid-state

*Corresponding author: junli@ksu.edu 


\section{Introduction}

Electrochemical capacitors (ECs) are an important class of electrochemical energy storage devices that bridge the gap between conventional dielectric or electrolytic capacitors and batteries. ECs are known for their high power density, long cycle life, low environmental impact, and high safety[1-4]. Electric double-layer-capacitors (EDLCs or supercapacitors) are the most widely studied class of ECs which physically stores charge by forming an electric double-layer at the interfaces between the electrode and the electrolyte [5, 6]. High surface area carbon materials such as activated carbon (AC) [7], carbon fibers [8],multi-walled and single-walled carbon nanotubes [9, 10], graphene [11], carbon aerogels [12], and carbide-derived carbon (CDC)[13]are typically used as electrode materials for EDLCs. The conventional EDLCs using high surface area activated carbon electrodes and non-aqueous liquid electrolytes represents the current state of the art [2]. The most common cause of failure of such devices is related to the electrolyte leakage [14]. Since the maximum specific energy of the device is proportional to the square of the cell voltage $\left(E=1 / 2 \cdot C V^{2}\right)$, the electrolyte is important in determining the specific energy and safety of the EDLCs. Along this direction, several attempts have been made to replace the liquid electrolyte with safer solid and gel electrolytes [14-19].

However, since theelectrochemical device involves ionmovement in the cell, adecrease in ionic mobility by solidification of electrolyte leads tolower power performance of the devices. Thus, a gel electrolyte with high ionic mobility and good dimensional/mechanical stability is preferred over all-solid electrolytes. The fundamentalconcept of gel-polymers are the immobilization/solidification of liquid electrolyte (ionic liquid or an ionic salt dissolved inan organic solvent) using a small amount of polymer materials. Thus, the gel polymer electrolytes

possess both the cohesive properties of solids and the diffusive transport properties of liquids[18].There are somereports that EDLCs using a gel electrolyte show high specific 
capacitance and specific energy but specific power values are still low compared to liquid systems[20-22]. More recently, solid-like gel electrolyte based on the immobilizing of room temperature ionic liquids (RTILs) using poly(vinylidene fluoride-co-hexafluoropropylene) (PVdF-HFP), poly(ethylene oxide) (PEO) and silica as matrix have been reported [9, 23, 24]. However, high viscosity and low ionic conductivity compared to the conventional liquid electrolyte is an issue limiting the power and temperature range of gel electrolyte based supercapacitors[24].

Recently, plastic crystalline succinonitrile ( $\mathrm{SN}$ ) has been used as solid solvent/plasticizer to enhance the ionic mobility in the polymer-based electrolytes [25-27]. Plastic crystals display short range rotational disorder but retaining long range transitional order that result in greater plasticity and enhanced diffusivities compared to rigid crystals[28]. SN possesses high dielectric constant $(\varepsilon)$ of 55 at $25{ }^{\circ} \mathrm{C}$ due to its polar character and hence shows ability to dissociate salts for high ionic conductivity [28]. In gauche-trans isomer from, which involves rotation of molecules about the central C-C bond, SN molecules help in enhancing the ionic mobility in the electrolytes via paddle-wheel mechanism[26, 28, 29]. The SN/lithium salt-based plastic crystal electrolyte shows a high ionic conductivity $\sim 10^{-3} \mathrm{~S} \mathrm{~cm}^{-1}$ at room temperature. However, the SN/lithium salt-based system shows poor mechanical properties due to their excessively plastic and liquid-like behavior at room temperature [28].To improve the mechanical properties, plastic crystal electrolytes are combined with a polymer matrix (e.g. PVdF-HFP, PEO etc.) to develop solid electrolytes for Li-ion batteries and EDLCs [30, 31]. Hashmi and co-workers reported the first study on a SN based gel polymer electrolyte for EDLCs application. Their PVdF-HFP based electrolyte system comprises 75 wt.\% SN and only 5 wt.\% IL. The ILs are used in place of conventional salt (such as lithium salt) in the SN based polymer electrolytes. Since these 
electrolytes contain large amount of non-ionic SN, the EDLC cells show very high equivalent series resistance (ESR) [31].

In this paper, we propose to develop a solid-state electrolyte by combing the properties of ionic liquids and SN. We used SN as non-ionic additives in PVdF-HFP gel matrix to improve the performance of IL-based gel electrolyte along with maintaining the electrical, electrochemical and mechanical properties of the gel electrolyte. RTILs are solvent-free salts with high electrochemical potential window and known for nonflamability and low vapor pressure whereas SN help to increase the ion dissociation and ionic mobility. To prepare gel polymer electrolytes, PVdF-HFPis used as host polymer and ionic liquid 1-butyl-3-methylimidazolium tetrafluoroborate $\left(\mathrm{BMImBF}_{4}\right)$ as ionic salt. The PVdF-HFP/IL/SN based gel electrolytes were combined with activated carbon electrode to fabricate solid-state supercapacitors. The electrochemical characterization of IL/SN gel based EDLCs were carried out at room temperature as well as in a wide temperature range from -30 to $80{ }^{\circ} \mathrm{C}$. The fabricated solid-state supercapacitor devices show high specific energy and specific power, good rate kinetics and excellent cycling stability.

\section{Experimental}

\subsection{Synthesis and characterization of gel polymer electrolyte}

The co-polymer, poly(vinylidenefluoride hexafluoropropylene), (PVdF-HFP, Mw 400,000), ionic liquid 1-butyl-3-methylimidazolium tetrafluoroborate(BMImBF $4, \quad \geq 98.0 \%)$ and succinonitrile (SN, 99\%) werepurchased from Sigma-Aldrich and used without further purification.The ionic liquid $\mathrm{BMImBF}_{4}$ was vacuum dried overnight at $80{ }^{\circ} \mathrm{C}$ before use. The gel polymer electrolytes were prepared by a solution cast method. The 0.5 gof the host polymer PVdF-HFP was separately dissolved in 8 mlacetone. The SN was dissolved in IL in different weight ratios. The IL/SN mixtures were mixed with PVdF-HFP solutions and stirred 
magnetically for $10 \mathrm{~h}$. Theweight ratio of the PVdF-HFP to IL/SN was kept at 1:4 and ratio of IL to SN was varied. The mixtures were cast over glass petri dishes in the argon filled glove box and allowed to evaporate acetone slowly. Finally, free-standing, flexible gel electrolyte films with a thickness of $\sim 300-400 \mu$ m were obtained. An optical image of a typical gel electrolyte is shown in Figure 1a. The flexible nature of mechanically stable film is shown in inset of Figure 1a. These electrolyte films were stored in an argon-filled glove box (MBraun, Stratham, NH, USA) tousefor electrical and thermal characterizations. For fabrication of solid-state supercapacitor cells, viscous ionic liquid gel polymer electrolytes in acetone was employed. The compositions of gel electrolytes are expressed as follows:

$\begin{array}{lll}\text { IL-gel } & : & \text { PVdF-HFP/IL/SN (1:4:0, w/w/w) } \\ \text { IL-SN-gel-1 } & : & \text { PVDF-HFP/IL/SN (1:3:1, w/w/w) } \\ \text { IL-SN-gel-2 } & : & \text { PVDF-HFP/IL/SN (1:2:2, w/w/w) } \\ \text { IL-SN-gel-3 } & : & \text { PVDF-HFP/IL/SN (1:1:3, w/w/w) }\end{array}$



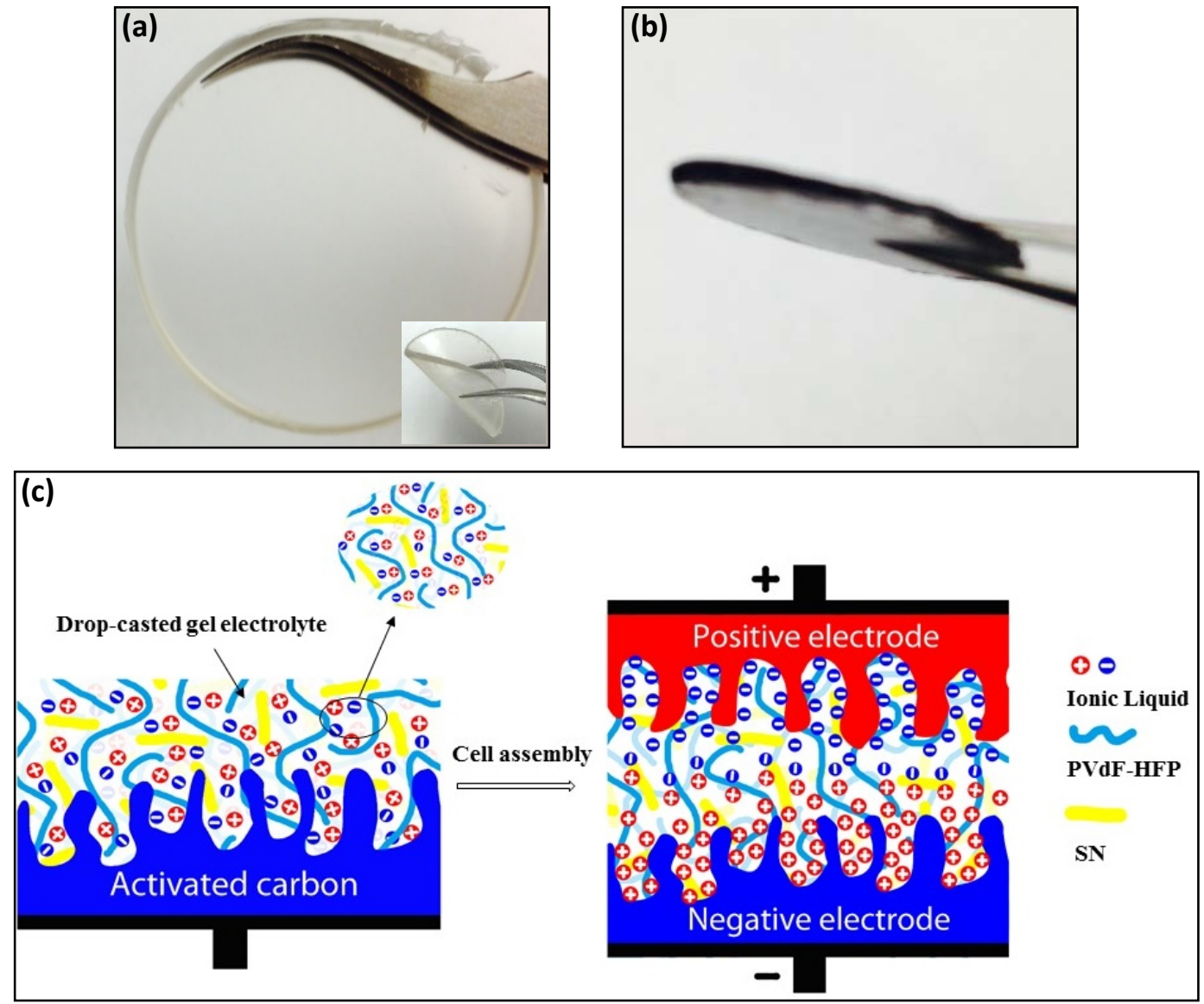

Figure 1: (a) Optical image of a gel polymer electrolytes film. The flexible nature of the gel film is shown in inset. (b) Optical images of a fabricated solid-state EDLC cell. (c) Schematic illustrations of the solid-state EDLC cell construction.

The ionicconductivity measurements of the gel polymer electrolyte films were carried out by electrochemical impedance spectroscopy (EIS)analysis of a cell, in which the electrolyte film was sandwiched between two symmetrical stainless-steel (SS) electrodes.The impedance 
measurements were performed using a CHI 760D electrochemical work station (CH Instruments, Austin, TX) in the frequency range from 1 to $100 \mathrm{kHz}$ with a signal level of $10 \mathrm{mV}$ between -30 to $80{ }^{\circ} \mathrm{C}$. The electrochemical stabilitywindow of the ionic liquid $\mathrm{BMImBF}_{4}$ and gel electrolyte films were determined by the linear sweepcyclic voltammetry. For this study, cells were assembled by sandwiching the gel electrolyte films between a stainless steel working electrode and a stainless steel counter (and reference) electrode. The thermal stability of the gel electrolytes were tested by differential scanning calorimetry (DSC) and thermo-gravimetric analysis (TGA). DSC was performed from -85 to $250{ }^{\circ} \mathrm{C}$ at a heating rate of $5{ }^{\circ} \mathrm{C} \mathrm{min}{ }^{-1}$ in a static nitrogen atmosphere using DSC system Q200 (TA Instruments, TX, USA). TGA was performed from room temperature to $550{ }^{\circ} \mathrm{C}$ under a dynamic dry nitrogen atmosphere at a heating rate of $10{ }^{\circ} \mathrm{C} \mathrm{min}{ }^{-1}$ using Pyris 1 TGA system (PerkinElmer, Waltham, MA, USA).

\subsection{Fabrication and characterization of solid-state supercapacitor cells}

Activated carbon (AC) YP-50F was purchased from Kuraray Chemical Co., Ltd. (Okayama, Japan) and vacuum dried overnight at $\sim 110{ }^{\circ} \mathrm{C}$ before use.The $\mathrm{N}_{2}$ adsorption/desorption isothermof the AC was obtained by a Micromeriticsanalyzer (Model: Gemini VII 2390t, USA) at $77 \mathrm{~K}$. The sample was degassed at $\sim 300{ }^{\circ} \mathrm{C}$ for $1 \mathrm{~h}$ in a nitrogen atmosphere, prior to the gas adsorption experiment. The Brunauer-Emmett-Teller (BET) specific surface area was calculated using adsorption dataat the relative pressure range of 0.05-0.3. Figure S1 shows the isotherm of the AC which is close to the type-Iisotherm, indicating a large surface area from micropores. The BET surface area and porosity parameters of the AC are listed in Supplementary Information. The BET surface area of the AC is $~ 1716 \mathrm{~m}^{2} \mathrm{~g}^{-1}$ and total pore volume is $0.801 \mathrm{~cm}^{-3} \mathrm{~g}^{-1}$.

The composite carbon electrodes were prepared by mixing activated carbon, Super-C65 conductive additive (Timcal, Cleveland, USA) and PVdF-HFP binder in acetonein a ratio of 75:15:10 (w/w). The slurry was casted onto flexible graphite sheet(0.4 mm thick; FiberMaterials 
Inc., USA). The activated carbon mass loading was $2.7 \mathrm{mg} \mathrm{cm}^{-2}$ with thickness $\sim 100 \mu \mathrm{m}$. The electrodes were cut into disks of $16 \mathrm{~mm}$ in diameter (electrode surface area $\sim 2.0 \mathrm{~cm}^{2}$ ) to fabricate supercapacitor cells, as shown in Figure S2a. The activated carbon electrodes were placed in vacuum oven and dried at $110{ }^{\circ} \mathrm{C}$. The solid-state supercapacitor cells fabrication procedure with different composition of gel polymer electrolytes is illustrated in Figure 1c. In this procedure, the highly viscous gel polymer electrolyte solution was drop-casted over the two activated carbon electrodes and allowed acetoneto evaporateslowly in an argon-filled glove box. The two similarly processed electrodes were pressed over each other to form the solid-state cell. The digital image of a typical solid-state supercapacitor cell is shown in Figure 1b. Such fabricated cells were placed into 2032 coin cells for electrochemical characterization (Figure S2). For comparison, supercapacitor cell with pure IL was fabricated by using fiberglassseparator soaked with IL.

Electrochemical performances of the supercapacitorcells were tested by EIS, cyclic voltammetry (CV), and galvanostatic charge-discharge method. The EIS measurements of supercapacitor cells were carried out inthe $100 \mathrm{kHz}$ to $1 \mathrm{mHz}$ frequency range at a signal level of $10 \mathrm{mV}$. The overallcell capacitance $\left(\mathrm{C}_{\text {cell }}\right)$ is evaluated from the imaginary part Z” ofimpedance using the expression:

$$
C_{\text {cell }}=\frac{-1}{\omega Z^{\prime \prime}}
$$

where $\omega$ is the angularfrequency of the applied signal.The CV was carried out atdifferent scan rates from 5 to $200 \mathrm{mV} \mathrm{s}^{-1}$ between a potential range of 0 and $2.5 \mathrm{~V}$. The overallcell capacitance $\left(\mathrm{C}_{\text {cell }}\right)$ from this technique were evaluated using the relation:

$$
C_{\text {cell }}=\frac{1}{2 v \Delta V} \oint i(V) d V
$$


where $v$ is scan rate and $\Delta \mathrm{V}$ is cell voltage. The galvanostatic charge-discharge tests were performed at different constant current density from $0.18 \mathrm{~A} \mathrm{~g}^{-1}$ to $8 \mathrm{~A} \mathrm{~g}^{-1}$ in the potential range of 0 to $2.5 \mathrm{~V}$. The overallcell capacitance $\left(\mathrm{C}_{\text {cell }}\right)$ was calculated from the discharge profiles by using the equation:

$$
C_{\text {cell }}=\frac{i \cdot \Delta t}{\Delta V}
$$

Where $i$ is the constant discharge current, $\Delta \mathrm{t}$ is the discharge time, $\Delta \mathrm{V}$ is the voltage dropupon discharging in time $\Delta \mathrm{t}$ (excluding the IR drop).

The specificcapacitance $\left(\mathrm{C}_{0}\right.$, in $\left.\mathrm{F} \mathrm{g}^{-1}\right)$ of activated carbon was calculated from the overallcell capacitance $\left(\mathrm{C}_{\text {cell }}\right)$ using the equation:

$$
C_{o}=\frac{2 C_{\text {cell }}}{m}
$$

wherem is the mass of the active material (activated carbon)per electrode (in g).Specific energy (E) and specific power (P) of supercapacitor cells were calculatedby using the equations:

$$
\begin{gathered}
E=\frac{1}{2}\left(\frac{C_{o}}{4}\right)(\Delta V)^{2} \\
P=\frac{\Delta V^{2}}{4 m \cdot E S R}
\end{gathered}
$$

where $C_{0}$ is the specific capacitance of single electrode, $\Delta \mathrm{V}$ is the cell voltage and $\mathrm{m}$ is the mass of the active electrodematerial per electrode. Equivalent series resistance (ESR, in $\Omega . \mathrm{cm}^{2}$ ) is evaluated from following equation:

$$
E S R=\frac{\Delta V_{I R}}{2 \cdot i}
$$

where $\Delta \mathrm{V}_{I R}$ is the ohmic drop when the polarity of the current is reversed and $i$ is the current density (in $\mathrm{A} \mathrm{cm}^{-2}$ ). All the electrochemicalmeasurements were conducted with a CHI 760D Electrochemical Workstation ( $\mathrm{CH}$ Instruments, Austin, TX). Long cycling stability test was 
performed using an MTI 8 channel battery analyzer (MTI Corporation, Richmond, CA). Electrochemical measurements were achieved at various temperature range from -30 to $80{ }^{\circ} \mathrm{C}$ using anEspec temperature and humidity chamber (Model: SH-241, Japan).

\section{Results and discussion}

\subsection{Electrochemical and thermal stability of gel polymer electrolytes}

The room temperature $\left(20{ }^{\circ} \mathrm{C}\right)$ ionic conductivity of the $\mathrm{IL} \mathrm{BMImBF}_{4}$ and different compositions of gel polymer electrolytes is listed in Table 1. The pure ILexhibits an ionic conductivity of $\sim 4.03 \times 10^{-3} \mathrm{~S} \mathrm{~cm}^{-1}$ at room temperature. The IL-gel, a blend of PVdF-HFP and IL in the ratio of 1:4 (w/w), shows slightly lower conductivity $\left(1.79 \times 10^{-3} \mathrm{~S} \mathrm{~cm}^{-1}\right)$ compared to the pure IL. However, the gel film obtained in the form of a self-standing film shows good dimensional stability.The slightly lower conductivity of IL-gel s suggests that blending the IL with the polymer PVdF-HFPoccurs at the molecular level. It is well reported that the ionic conductivity would not bedecreased to such an extent if the blending were at the microscopic level rather than the molecular level[32, 33]. On partially replacing the IL content by SN in the gel electrolytes, the conductivity increases up to $6.4 \times 10^{-3} \mathrm{~S} \mathrm{~cm}^{-1}$ for IL/SN ratio of 2:2 (w/w). On further reduction of IL content (for IL-SN-gel-3), the conductivity decreases slightly, however, it is still higher compared to IL-gel. The presence of non-ionic and highly polar plastic-crystalline SN plays a crucial role to enhance the ionic conductivity of the gel polymer electrolytes. Plastic-crystalline SN possesses high molecular diffusivity, waxy nature, and goodsolvating power via low melting temperature $\left(\mathrm{Tm} \sim 62^{\circ} \mathrm{C}\right)$ and high dielectric constant $(\varepsilon$ 55) which help to reduce the crystallinity of PVdF-HFP[28].The SN acts as a solid plasticizer due to the orientationally disorder structure, responsible for the rotational motion of the molecules, which helps in the dissociation of IL ions and increases the mobility of ions results

high ionic conductivity [28]. The IL-SN-gel-2 shows highest conductivity $\sim 6.4 \times 10^{-3} \mathrm{~S} \mathrm{~cm}^{-2}$ at 
room temperature. All the gel electrolyte films are self-standing and flexible with good mechanical stability.

Figure 2(A) shows the temperature dependence of the electrical conductivity of different composition of the gel polymer electrolytes in the temperature range from -30 to $80^{\circ} \mathrm{C}$. The $\log$ $\sigma$ vs. 1/T plots show a non-linear behavior, which follows the non-Arrhenius Vogel-TammenFulcher (VTF) equation:

$$
\sigma(T)=A T^{-1 / 2} \exp \left(\frac{-B}{T-T_{0}}\right)
$$

where, $\mathrm{A}$ is the pre-exponential factor, $T_{\mathrm{o}}$ is the equilibrium glass transition temperature which is usually close to the $T_{g}$ values, and $B$ is a pseudo-activation energy which is associated with the critical free volume for the charge-carriers motion. The VTF model is commonly employed to interpret ion transport data in amorphous polymer electrolyte above the glass transition[34]. The temperature dependent of conductivity measurement shows that SN containing gel electrolytes exhibits ionic conductivity of $\sim 1.5 \times 10^{-2} \mathrm{~S} \mathrm{~cm}^{-1}$ at $80{ }^{\circ} \mathrm{C}$ and $\sim 5 \times 10^{-4} \mathrm{~S} \mathrm{~cm}^{-1}$ at $-30{ }^{\circ} \mathrm{C}$, which is almost one order of magnitude higher than those without SN (i.e. IL-gel), particularly at lower temperatures. These further confirm the crucial role of SN as non-ionic and highly polar matrix to dissociate IL ions, which help to improve conductivity at lower temperatures.Figure 2(B) compares the overall electrochemical stability window (ESW) of the pure IL, IL-gel and IL-SNgel-2 electrolytes. As expected, the stability window of the IL and gel electrolytes is comparable and only minor differences are observed for the reduction of the cations BMIm ${ }^{+}$in the IL-gel and SN-IL-gel matrix. The ESW of IL-SN-gel-2 electrolyte has been observed from -2.9 to $2.5 \mathrm{~V}$ which is high enough to use as solid-state electrolytes/separators in the high-performance EDLCs. 

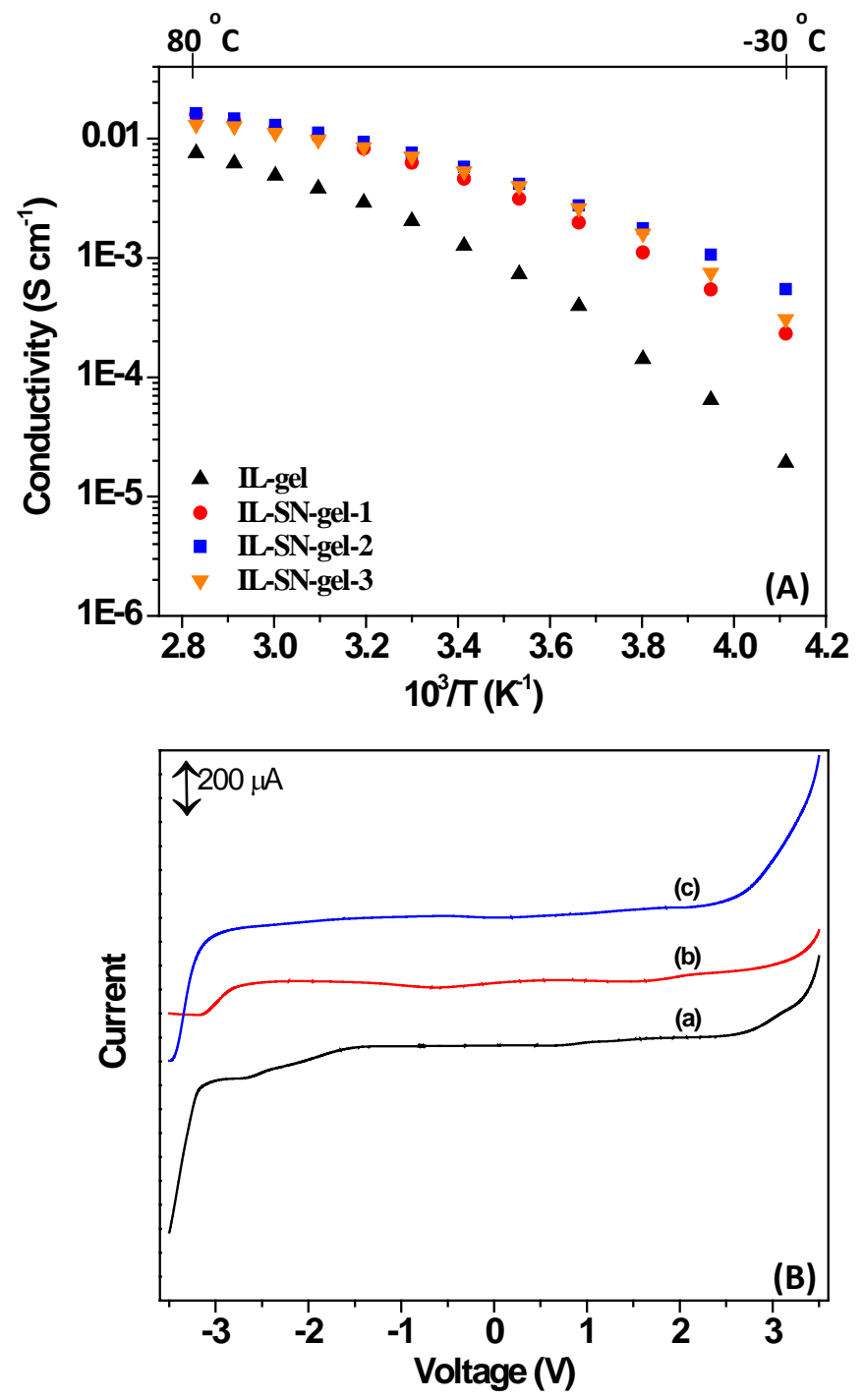

Figure 2: (A)Temperature dependence of ionic conductivity of gel polymer electrolyte containing different amount of SN and IL. (B) Linear sweep voltammetry responses of (a) IL, (b) IL-gel and (c) IL-SN-gel-2, recorded from symmetrical cells with two identical stainless steel (SS) electrodes at a scan rate of $5 \mathrm{mV} \mathrm{s}^{-1}$. Curves (a) and (c) are offset downward and upward by $200 \mu \mathrm{A}$ for clarity, respectively. 
The thermal stability of the gel polymer electrolytes were tested by DSCand TGA. The DSC curves of the host polymer PVdF-HFP, pure SN and different compositions of PVdF-HFP/IL/SN gel electrolytes are presented in Figure 3(A). Pure SN shows two characteristics peaks at $-26{ }^{\circ} \mathrm{C}$ and $59{ }^{\circ} \mathrm{C}$ (Figure 3A-b). The peak at $\mathrm{T}_{\mathrm{cp}} \sim-26{ }^{\circ} \mathrm{C}$ corresponds to a phase transition from a normal ordered phase with monoclinic structure to an orientationally disordered plastic crystalline phase with bcc structure and the peak at $\sim 59{ }^{\circ} \mathrm{C}$ is assigned as melting temperature of SN [28].The endothermicpeak at $142{ }^{\circ} \mathrm{C}$ corresponds to the melting point of crystalline phase of the hostpolymer PVdF-HFP (Figure 3A-a). Blending with IL BMImBF 4 (IL-gel) lowersthe melting point substantially to $106{ }^{\circ} \mathrm{C}$. The melting peakbecomes more asymmetric and this is attributed to the presence of liquid components in larger proportion (1:4 ratio) that causes an increase in the amorphous content in the overallmaterial (Figure 3A-c). Anendothermic peak at $-60{ }^{\circ} \mathrm{C}$ has been observed whichis assigned to the melting temperature of entrapped IL $\mathrm{BMImBF}_{4}$. On addition of SN (and by the amount of IL), there is no melting peak of SN appears for IL-SN-gel-1 and IL-SN-gel-2 (Figure 3A-d and e) whereas for IL-gel-3 (in which IL/SN ratio is $1: 3$ ) the melting peak of $\mathrm{SN}$ shifted from $59{ }^{\circ} \mathrm{C}$ to $9{ }^{\circ} \mathrm{C}$ (Figure 3A-f). However, insignificant change in $\mathrm{T}_{\mathrm{cp}}$ of $\mathrm{SN}$ has been observed for all the gel compositions and $\mathrm{T}_{\mathrm{cp}}$ appears $\sim-35$ to -40 ${ }^{\circ} \mathrm{C}$. The absence or large reduction in melting peak of SN and presence of phase transition peak $\left(T_{c p}\right)$ in gel polymer electrolytes indicate that the phase transition of SN occurs from ordered phase to the disordered (amorphous) phase in the presence of IL. Thus, the electrolyte films remain stable inthe same gel phase (amorphous) over a substantially wide temperature rangefrom -30 to $90{ }^{\circ} \mathrm{C}$ which shows a good agreement with the temperature dependence of the conductivity study. The wide temperature range and high conductivity values of these IL/SN based gel electrolytes satisfy the requirements for solid-state supercapacitor applications. 

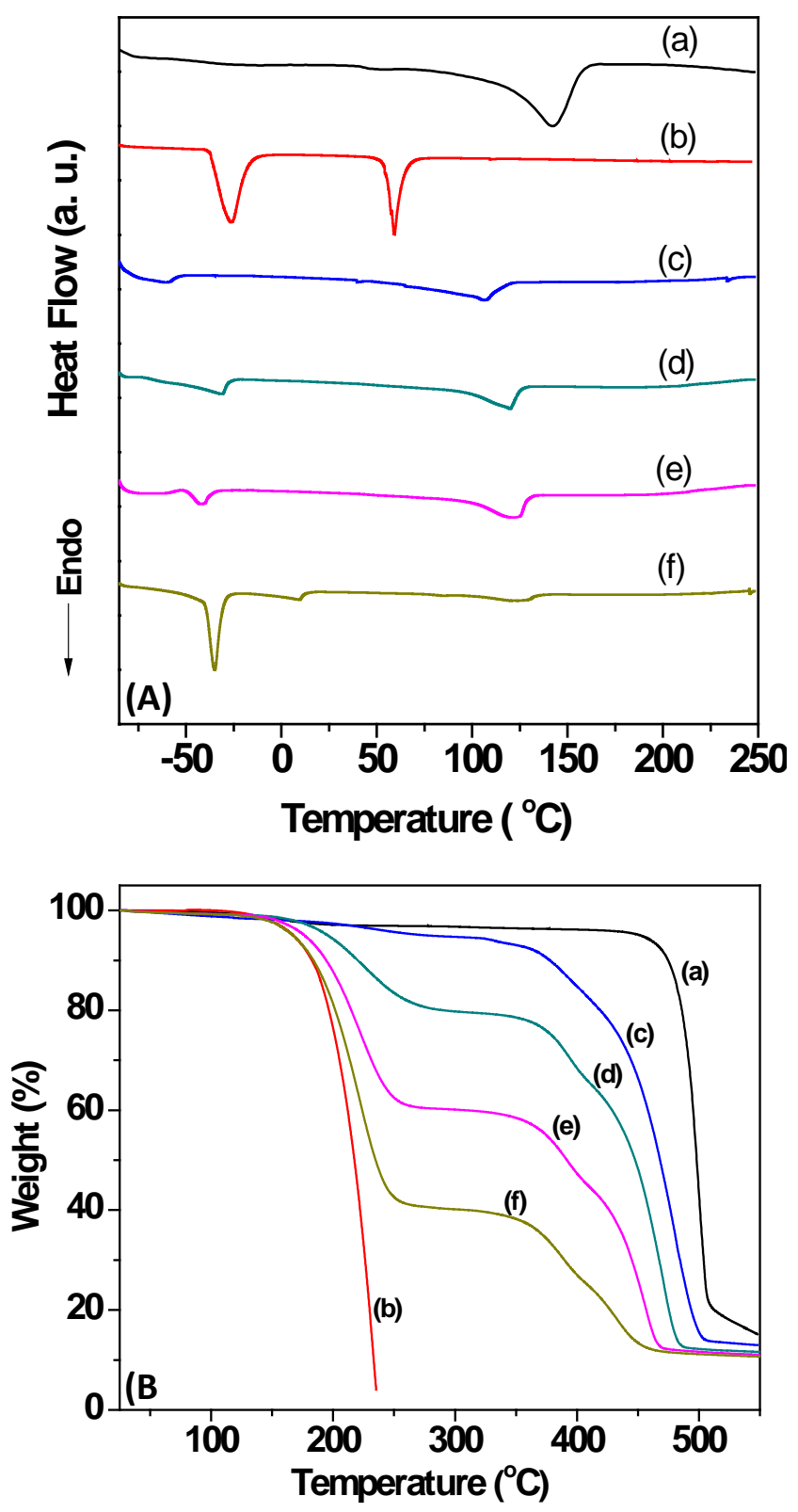

Figure 3: (A)DSC and (B) TGA curves of (a) pure PVdF-HFP film, (b) pure SN, (c) IL-gel, (d) IL-SN-gel-1, (e) IL-SN-gel-2, and (f) IL-SN-gel-3. 
Figure 3(B) shows the TGA curves of the host polymer PVdF-HFP, pure SN and different compositions of PVdF-HFP/IL/SN gel electrolytes. The copolymer PVdF-HFP is thermally stable up to $450{ }^{\circ} \mathrm{C}$ with almost no weight loss in this temperature range. Pure SN remains thermally stable up to $\sim 130{ }^{\circ} \mathrm{C}$ and after this temperature $\mathrm{SN}$ starts evaporate, as observed in Figure 3B(b). IL component ions decompose at $\sim 350{ }^{\circ} \mathrm{C}$ and hence, IL-gel is stable up to $350{ }^{\circ} \mathrm{C}$. All the other gel electrolytes contains SN are stable up to $130{ }^{\circ} \mathrm{C}$ and after this temperature SN starts evaporate. Also, a plateau region has been observed between 250 to $350{ }^{\circ} \mathrm{C}$ for the PVdFHFP/IL/SN gel electrolytes corresponding to the thermal stability range of IL.

\subsection{Performance characteristics of supercapacitor cells}

The electrochemical performance of the gel electrolyte based supercapacitor cells with two identical activated carbon electrodes was evaluated by cyclic voltammetry (CV) and galvanostatic charge discharge tests. Figure S3 shows the charge-discharge curves of a typical symmetrical cell with IL-SN-gel-2 as the electrolyte between two identical activated carbon electrodes at a constant current density of $3 \mathrm{~mA} \mathrm{~cm}-2\left(\sim 1.1 \mathrm{~A} \mathrm{~g}^{-1}\right)$ asthe upper-limit cell voltage was changedfrom 2.0 to $3.5 \mathrm{~V}$. The distortion of the triangular shape observed near $3.0 \mathrm{~V}$ indicatesthe occurrence of Faradaic reactions associated with the decomposition of the gel electrolyte. To avoid this, later electrochemical characterization of the supercapacitor cells was carried out from 0 to $2.5 \mathrm{~V}$ operative voltage.Figure4Ashows the comparative CV responses of the supercapacitor cells with different gel polymer electrolytes and pure IL at a scan rate of 10 $\mathrm{mV} \mathrm{s}^{-1}$ between 0 to $2.5 \mathrm{~V}$ at RT. The CV of gel polymer electrolyte based cells is dominated by rectangular shaped features, indicatingthat the major capacitive storage mechanism is the EDLC at the interface of gel electrolyte and the porous activated carbonelectrodes. The slightly larger baseline currents from 1.5 to $2.5 \mathrm{~V}$ cell voltage are attributed to reversible Faradaic reactions of the oxygen-containing groups at the surface of activated carbon electrodes, which are known to 
contribute additional pseudocapacitance, consistent with CV profiles of activated carbon in general organic electrolytes [35].Clearly, the cell with IL-SN-gel-2 gel electrolyte (curve d in Figure 4A) shows the highest capacitive storage among all gel electrolyte compositions. The CV curve of pure IL based cell shows significant distortion from rectangular shape, even at $10 \mathrm{mV} \mathrm{s}^{-}$

${ }^{1}$ scan rate, indicates the higher resistive values due to the high viscosity of the IL $\mathrm{BMImBF}_{4}$ (109 cP at $25{ }^{\circ} \mathrm{C}$ )[36].Although rectangular shape for gel polymer electrolyte based cells was maintained at for higher scan rates, distortion was observed at $\sim 100 \mathrm{mV} \mathrm{s}^{-1}$, as shown in Figure S4a.
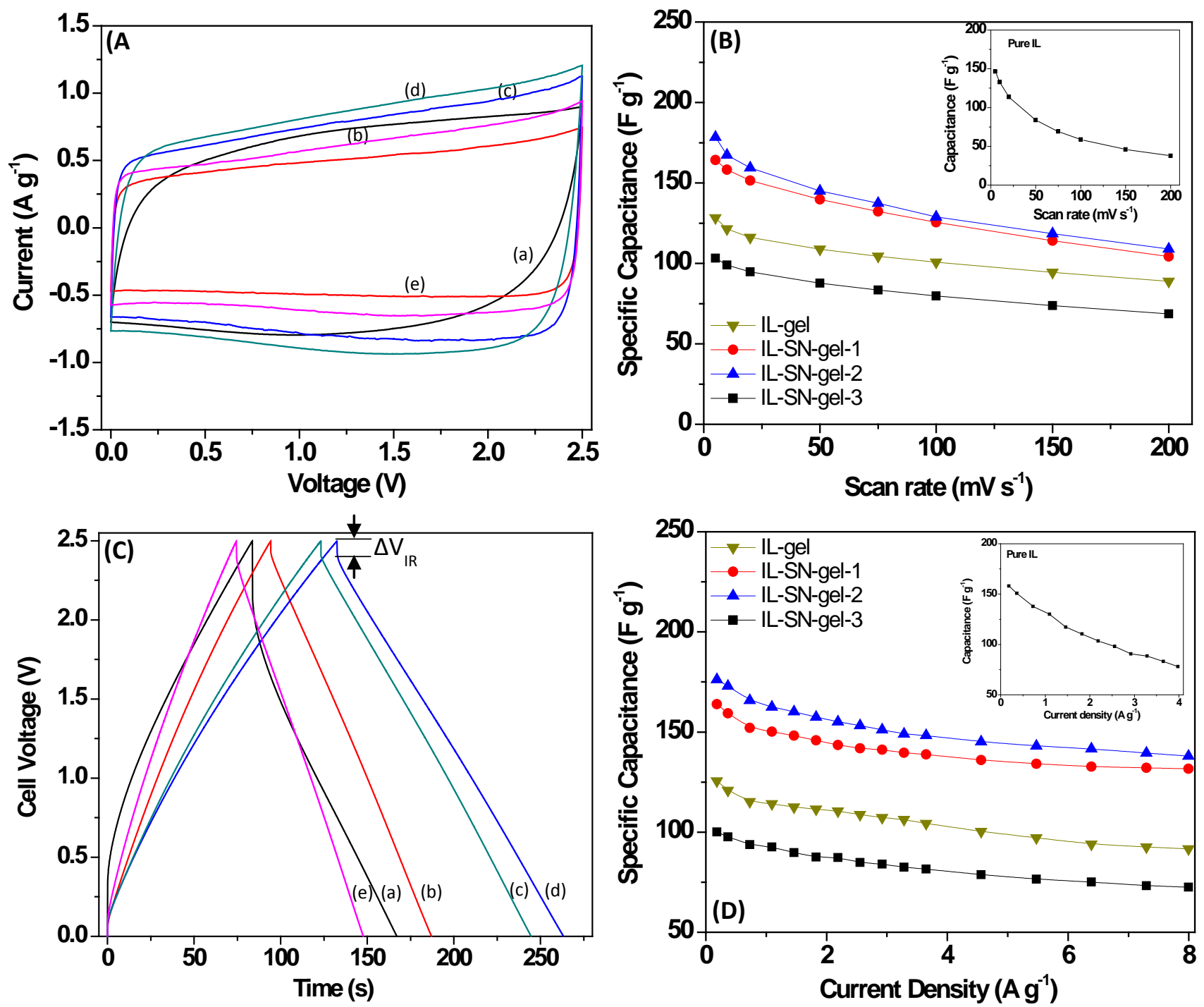
Figure 4: (A)Comparative CV patterns at a scan rate of $10 \mathrm{mV} \mathrm{s}^{-1}$ forsymmetrical EDLC cellsconsisting of two identical activated carbon electrodes and different compositions of the gel polymer electrolytes and pure IL. (B) Variation of the specific capacitance of different EDLC cellsas a function of the scan rate. (C)Charge-discharge curves at constant current density of 1.5 $\mathrm{A} \mathrm{g}^{-1}$ of EDLC cells with different composition of the gel polymer electrolytes and pure IL. (D) Variation of the specific capacitance of different EDLC cells as a function of charge-discharge constant current densities. Inset of Figure (B) and (D) shows the variation of the specific capacitance of EDLC with pure IL. In Figure (A) and (C): (a) pure IL, (b) IL-gel, (c) IL-SN-gel1, (d)IL-SN-gel-2, and (e) IL-SN-gel-3.

The capacitive retentionshowed by the supercapacitor cells during $\mathrm{CV}$ measurements at various scan rates from 5 to $200 \mathrm{mV} \mathrm{s}^{-1}$ is shown in Figure 4(B). Inset of Figure 4(B) shows the capacitive retention with scan rates for cell with pure IL. The specific capacitance was evaluated using equation (2) and (4). The supercapacitor cell with IL-SN-gel-2 gel electrolytes shows highest specific capacitance $178 \mathrm{~F} \mathrm{~g}^{-1}$ at $5 \mathrm{mV} \mathrm{s}^{-1}$ and $109 \mathrm{~F} \mathrm{~g}^{-1}$ at $200 \mathrm{mV} \mathrm{s}^{-1}$ (with respect to the mass of activated carbon). The cell with IL-gel (without SN) shows specific capacitance of $128 \mathrm{~F}$ $\mathrm{g}^{-1}$ at $5 \mathrm{mV} \mathrm{s}^{-1}$ and $89 \mathrm{~F} \mathrm{~g}^{-1}$ at $200 \mathrm{mV} \mathrm{s}^{-1}$, whereas cell with pure IL shows specific capacitance of $146 \mathrm{~F} \mathrm{~g}^{-1}$ at $5 \mathrm{mV} \mathrm{s}^{-1}$ and $37 \mathrm{~F} \mathrm{~g}^{-1}$ at $200 \mathrm{mV} \mathrm{s}^{-1}$. The pure IL based cell show larger capacitance dropat higher scan ratescompared to IL-gel but its specific capacitance is much higher at low scan rate $\left(5 \mathrm{mV} \mathrm{s}^{-1}\right)$. Furthermore, the capacitance in the gel electrolytes can be modulated by balancing two factors, i.e. the charge carrier density and ionic mobility, with the introduction of SN. This enhances the mobility of the ionic species and the overall ionic conductivity, resulting in much higher specific capacitance at all scan rates with IL-SN-gel-2 than simple IL-gel electrolytes.However,compared to the IL-gel based cell, the capacitance of the IL-SN-gel-2 based cell drops slightly faster as the scan rate is increased. This is because, in 
the gel electrolytes, the charge carrier density plays a more crucial role than the viscosity (and hence mobility) at higher scan rate. The presence of the non-ionic SN in the IL-SN-gel-2 electrolyte lowers the charge carrier density and thus causes slightly lower capacitance retention capability vs. the scan rate. The gel polymer electrolyte with higher content of SN (IL-SN-gel-3) shows specific capacitance of $103 \mathrm{~F} \mathrm{~g}^{-1}$ at $5 \mathrm{mV} \mathrm{s}^{-1}$ and $68 \mathrm{~F} \mathrm{~g}^{-1}$ at $200 \mathrm{mV} \mathrm{s}^{-1}$ which is lower than IL-gel based cell. Thus, the higher content of non-ionic SN in the gel electrolyte reduce the specific capacitance. However, SN containing other gel polymer electrolytes show higher specific capacitance compared to IL-gel which confirms that SN addition on gel electrolyte is beneficial for better capacitive storage properties.

To further investigate the performance of the supercapacitor cells with different compositions of gel polymer electrolytes, galvanostatic charge discharge tests were carried out at constant current densities ranging from 0.18 to $8 \mathrm{~A} \mathrm{~g}^{-1}$ (Figure 4C\& D). Figure 4(C) shows the typical charge-discharge characteristics of supercapacitor cell with gel polymer electrolytes and pure IL at a constant current density of $1.5 \mathrm{~A} \mathrm{~g}^{-1}\left(\sim 4 \mathrm{~mA} \mathrm{~cm}^{-2}\right)$. Figure S4b shows the charge-discharge curves of a typical cell with IL-SN-gel-2 electrolyte at different current densities. All cells show linear discharge behavior with a small ohmic drop, which is in agreement with the non-faradaic capacitive charge-storage mechanism, as also observed from CV study. The ESR of each cell has evaluated, from the initial sudden drop in voltage observed in discharge profile of each cell, using equation (7). The supercapacitor cell with IL-gel has ESR value around $14 \Omega \mathrm{cm}^{2}$ which is much smaller than the ESR value of pure IL based cell $\left(\sim 55 \Omega \mathrm{cm}^{2}\right)$. The supercapacitor cells with IL/SN based gel electrolytes have nearly identical ESR values around $14-17 \Omega \mathrm{cm}^{2}$. The low ESR (IR drop) of IL/SN gel polymer electrolyte based solid-statesupercapacitor indicates that the internal resistance of thedevice is low which is important from the device applicationpoint of view. The ESR values isabout three times higher compared to the 
conventional organic liquid electrolyte based EDLC cells but comparable to the recently reported gel electrolyte based solid-state EDLCs/supercapacitors [37-40].The specific capacitances of activated carbon electrode calculatedfrom the different gel electrolyte based cells discharge profiles at different constant current density, using Equation (3) and (4), are plotted as afunction of the discharge current density and presented in Figure 4D. Inset of Figure 4D shows the specific capacitance versus current density plot derived from cell with pure IL. The cell with ILSN-gel-2 shows superior performance compared to the other gel electrolytes compositions. This cell shows specific capacitance of $176 \mathrm{~F} \mathrm{~g}^{-1}$ at current density of $0.18 \mathrm{~A} \mathrm{~g}^{-1}$ and $138 \mathrm{~F} \mathrm{~g}^{-1}$ at current density of $8 \mathrm{~A} \mathrm{~g}^{-1}$. The cell with pure IL show specific capacitance of $158 \mathrm{~F} \mathrm{~g}^{-1}$ at current density of $0.18 \mathrm{~A} \mathrm{~g}^{-1}$ and $77 \mathrm{~F} \mathrm{~g}^{-1}$ at current density of $4 \mathrm{~A} \mathrm{~g}^{-1}$. The high viscosity of the IL decreases the mobility of the ionic species and hence, the cell with pure IL shows lowercapacitance retention as thecharge-discharge rateis increased. The gel polymer electrolyte with higher content of SN (IL-SN-gel-3) shows specific capacitance of $100 \mathrm{~F} \mathrm{~g}^{-1}$ at $0.18 \mathrm{Ag}^{-1}$ and $72.5 \mathrm{~F} \mathrm{~g}^{-1}$ at $8 \mathrm{~A} \mathrm{~g}^{-1}$ which is lower than IL-gel based cell. This results is consistent with the CV performance of different supercapacitor cells. The superior performance of the optimized IL/SN gel electrolyte based supercapacitors indicate the advantage of using gel electrolyte instead of pure IL to get high specific capacitance and much better rate kinetics of the porous activated carbon electrode based supercapacitor cells.

EIS provides further information about the resistance (i.e. ESR) of the device and the time constant for charging and discharging. Figure 5a presents the Nyquist plot for supercapacitor cells with pure IL and different compositions of gel polymer electrolytes. The steep rising behavior of the Nyquist plots(parallel to Z”-axis) at low frequency region indicates thecapacitive behavior of all the supercapacitor cells. However, thelow frequency region of the cells with gel polymer electrolyte is closer to the ideal behavior compared to the pure IL cell. The steep rising 
capacitive response in the lowfrequency region accompanied with high frequency features owingto the bulk and interfacial properties of the supercapacitor cells.The ESR can be drawn from the intersection with the real axis of the Nyquist plots, as shown in the inset of Figure 5a. The cell with pure IL showing higher resistance $\sim 31.4 \Omega \cdot \mathrm{cm}^{2}$ whereas the cell with different composition of gel polymer electrolytes have a resistance in the range of $7.6-11.6 \Omega \cdot \mathrm{cm}^{2}$. For low frequency, specific capacitance is calculated by using equation (1) and (4). The cell with IL-SNgel-2 gel polymer electrolyte shows $126 \mathrm{~F} \mathrm{~g}^{-1}$ at $1 \mathrm{mHz}$ compared to $99 \mathrm{~F} \mathrm{~g}^{-1}$ for the cell with ILgel (without SN) electrolytes.However, the cell with gel electrolyte with higher content of SN (IL-SN-gel-3) shows lower specific capacitance than IL-gel based cell.

The frequency behavior of the supercapacitor cells with pure IL and different compositions of gel polymer electrolytes was analyzed using a complex capacitance model. The complex form of frequency-dependent capacitance can be defined as [41]:

$$
\begin{aligned}
& C(\omega)=C^{\prime}(\omega)-j C^{\prime \prime}(\omega) \\
& C^{\prime}=\frac{-Z^{\prime \prime}}{\omega Z^{2}} \\
& C^{\prime \prime}=\frac{Z^{\prime}}{\omega Z^{2}}
\end{aligned}
$$



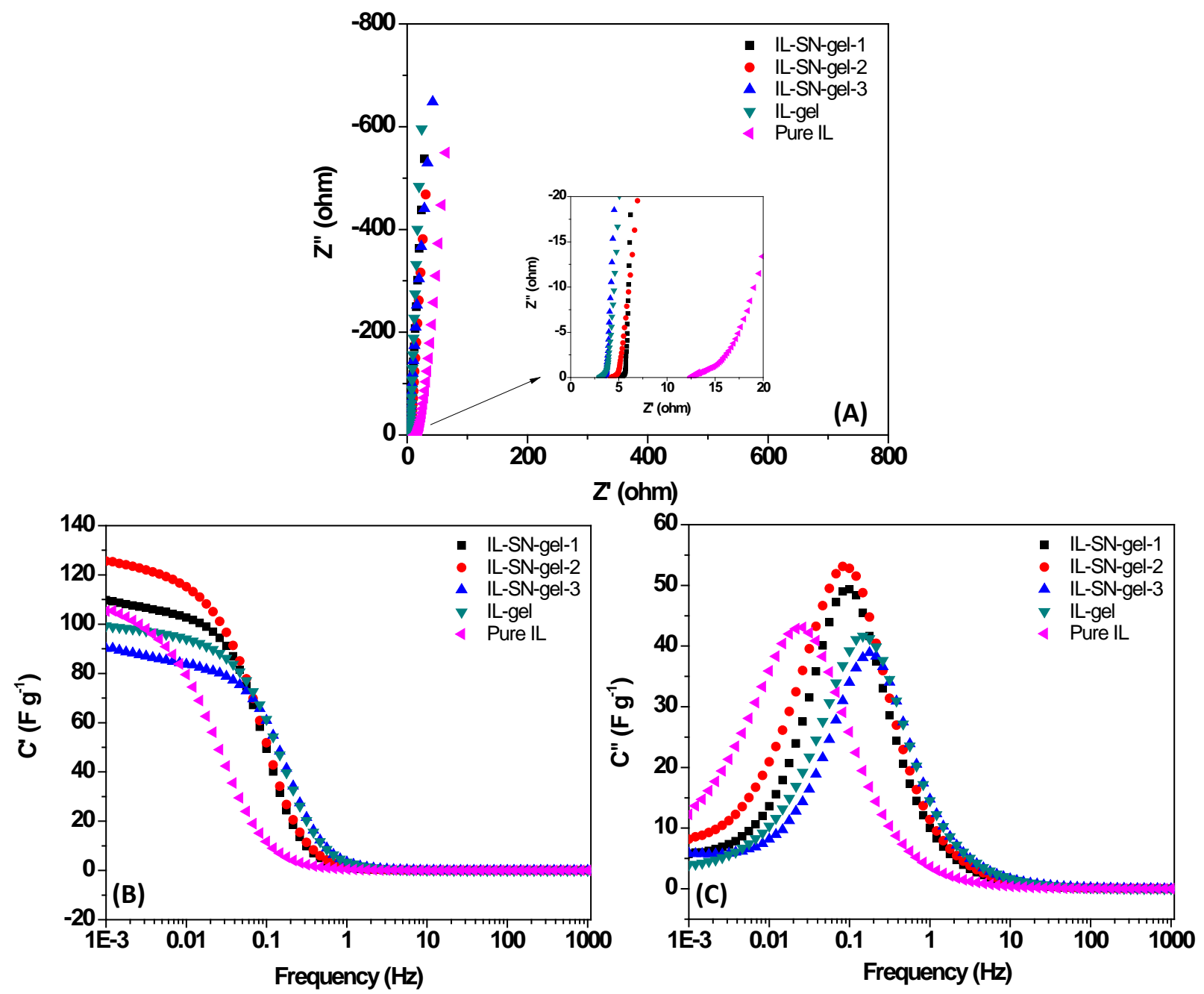

Figure 5: Frequency responses of EDLCs consisting of two identical activated carbon electrodes and different compositions of the gel polymer electrolytes and pure IL in a frequency range from $100 \mathrm{kHz}$ to $1 \mathrm{mHz}$. (A) Nyquist plot of EDLCs with different gel electrolytes and pure IL. (B) Real and (C) imaginary capacitance of cells with different electrolytes.

where $C^{\prime}$ is the real part and $C^{\prime \prime}$ is the imaginary part of the capacitance C.The real part $\left(C^{\prime}\right)$ is defined as the effective capacitance that the device can deliver and the imaginary part $\left(\mathrm{C}^{\prime \prime}\right)$ is related to the energy dissipation by an irreversible process that leads to hysteresis[42, 43]. The changes of real and imaginary part $\left(\mathrm{C}^{\prime}\right.$ and $\left.\mathrm{C}^{\prime \prime}\right)$ of the capacitanceas a function of frequency for 
all the supercapacitor cells are presented inFigure 5(b and c). The graph shows a transition from purely resistive behavior at high frequency (phase angle close to 0 ) to purely capacitive behavior at low frequency. For IL-SN-gel-2 based cell, phase angle approaches $-88^{\circ}$ at $1 \mathrm{mHz}$ which demonstrates a near ideal capacitive behavior. The capacitance of the device is given by maximum point of the real capacitance and Il-SN-gel-2 gel based cell shows the highest specific capacitance.

Figure 5c presents the evolution of the imaginary part of the capacitance versus the frequency. The imaginary part reaches a maximum at a specific frequency $f_{0}$, which defines the time constant (or relaxation time) $\tau_{0}=1 / f_{0}[41]$.This time constant marks the frontiers between resistive and capacitive behavior. The lower time constant shows that the rate kinetics is faster. However, time constant is strongly influence by the different parameters such as used electrolyte, conductivity, electrode thickness etc.[44]. In the present study, all the parameters are same (i.e. electrode material and thickness etc.) except electrolyte and their conductivity values. The time constant for IL-SN-gel-2 based cell is $11 \mathrm{~s}$ whereas IL-SN-gel-3 (with higher content of SN) cell time constant is $5.5 \mathrm{~s}$. Despite the use of solid-like gel polymer electrolytes, the value of time constant ranging from $5.5 \mathrm{~s}$ to $11 \mathrm{~s}$ is in the range as the one reported for liquid electrolytes which demonstrates the usefulness of gel polymer electrolytes for supercapacitors [19, 41]. The electrochemical performanceof supercapacitor cells with different composition of gel electrolytes are compared in Table 2.

Electrochemical performance of the supercapacitor cell in the wider temperature range is an important merit, particularly below the extreme temperature on earth. Figure 6(a and b) show the CVs of supercapacitor cell with IL-SN-gel-2 electrolyte at various temperatures from -30 to $80{ }^{\circ} \mathrm{C}$, recorded at $5 \mathrm{mV} \mathrm{s}^{-1}$ between 0 to $2.5 \mathrm{~V}$. The cell shows good capacitive response even down to $-30{ }^{\circ} \mathrm{C}$ and rectangular shape characteristic was achieved from -30 to $80{ }^{\circ} \mathrm{C}$. However, at 
the temperature below RT, the slope of the anodic current in CV reduced (Figure 6A) and CV profiles become closer to ideal rectangular shapes, indicating suppression of pseudocapacitance that is likely associated with reduced mobility of trapped moisture in the gel electrolyte. Accordingly, the series resistance is clearly increased as reflected in Figure 6C.Figures6(c and d) show Nyquist plots of the cell at corresponding temperatures which show a notable change in the ESR values at high frequencies. ESR value for the supercapacitor cell increases around 4 times from RT to $-30{ }^{\circ} \mathrm{C}$. Table 3 summarizes the specific capacitance, areal capacitance and ESR calculated from the Nyquist plots at a $10 \mathrm{mHz}$ form -30 to $80{ }^{\circ} \mathrm{C}$. The gel electrolyte based cells show wider electrochemical working temperature range which is superior compared to the recently reported literatures [24, 45]. 

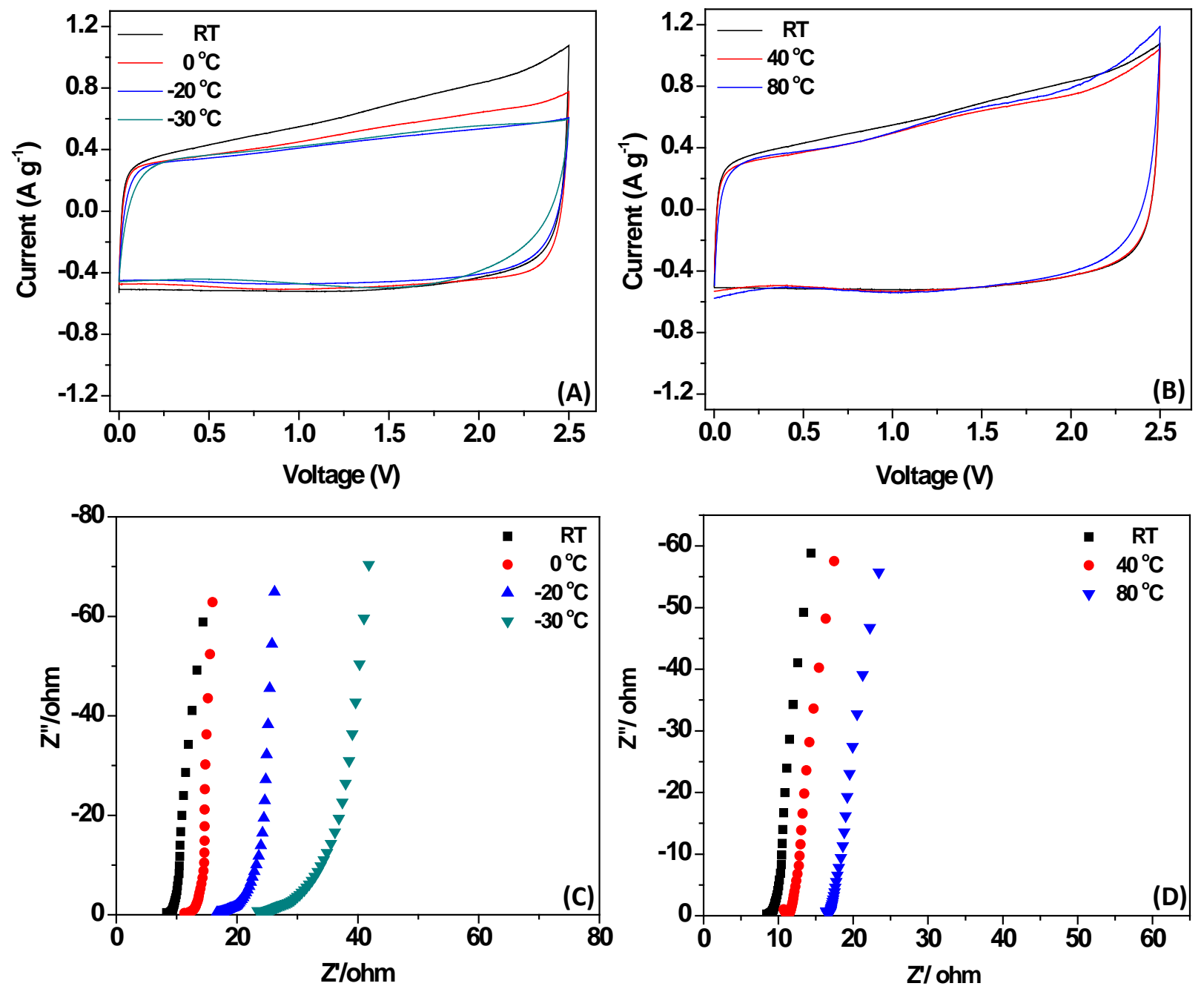

Figure 6:Electrochemical characterization of EDLC cells consisting of two identical activated carbon electrodes with the typical gel polymerelectrolyte IL-SN-gel-2 (cell area $\sim 1.4 \mathrm{~cm}^{2}$, mass of AC in one electrode $\sim 3.5 \mathrm{mg} \mathrm{cm}^{-2}$ ): (A and $\mathrm{B}$ ) CVs recorded at $5 \mathrm{mV} \mathrm{s}^{-1}$; (C and D) EIS Nyquist plots in the frequency range from $100 \mathrm{kHz}$ to $10 \mathrm{mHz}$. Panels (A and C) are at $\mathrm{T} \leq \mathrm{RT}$ and panels (B and $\mathrm{D}$ ) are at $\mathrm{RT} \leq \mathrm{T} \leq 80{ }^{\circ} \mathrm{C}$.

The self-discharge behavior, the spontaneous voltage drop when the cell is maintained without load, is one key concern for practical applications of supercapacitors. A solid-state supercapacitor cell with IL-SN-gel-2 electrolyte was charged to $2.5 \mathrm{~V}$ at $0.35 \mathrm{~A} \mathrm{~g}^{-1}$ followed by constant voltage charging for $1 \mathrm{~h}$. The open circuit voltage as a function of time was then 
measured and is presented in Figure 7. It took $25 \mathrm{~h}$ for the voltagedrop form $2.5 \mathrm{~V}$ to $1.5 \mathrm{~V}$ with a faster rate at the beginning. Thus, it gives around $40 \%$ decay in $25 \mathrm{~h}$, which is lower than those of the EDLCs with an organic liquid electrolyte system that generally shows around 60\% decay in $\sim 12 \mathrm{~h}[14,46]$.

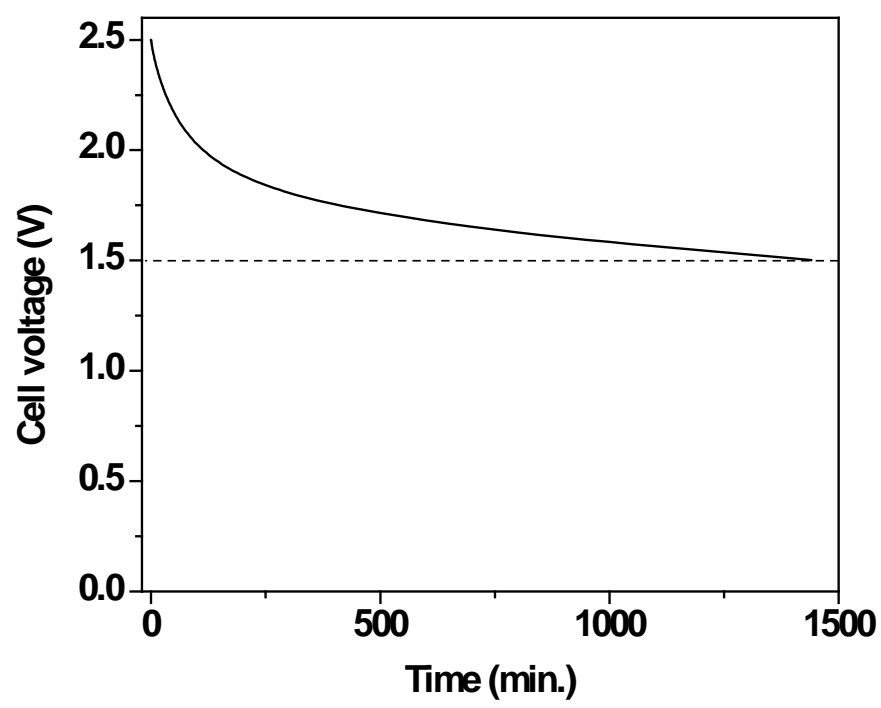

Figure 7:Self-discharge curve of the EDLC cell consisting of two identical activated carbon electrodes with IL-SN-gel-2 electrolyte after constant voltage charging. The charge was performed at $0.35 \mathrm{~A} \mathrm{~g}^{-1}$ to the full charge voltage $(2.5 \mathrm{~V})$ followed by constant voltage charging for $1 \mathrm{~h}$ at room temperature.

Long-term cycle stability is one of the most important parameter in supercapacitor applications. The cycling stability of the IL-gel and IL-SN-gel-2 electrolyte based solid-state supercapacitor cells was evaluated by galvanostatic charge-discharge cycling at a constant current density of $1.5 \mathrm{~A} \mathrm{~g}^{-1}$ over 10,000 continuous cycles in the voltage window 0-2.5 V. Figure8a shows the capacitance retention of the cells as a function of the charge-dischargecycle numbers. The IL-SN-gel-2 electrolyte based cell shows stable cycling performance after a decrease in the initial $\sim 100$ cyclesandthedevice retains $\sim 80 \%$ of the initial capacitanceafter10,000chargeanddischarge cycles, showing a very promising retention rate for supercapacitor cells. The IL-gel (without SN) based cell shows faster capacitance fading in the 
initial cycles and the capacitance further decreases gradually. This cell retains $\sim 65 \%$ of the initial capacitance after 10,000 cycles. Clearly, the addition of plastic crystalline SN improves the cycle stability significantly. Fig. S5 shows the charge-discharge curves at different cycle number during long-term stability test for IL-SN-gel-2 based supercapacitor cell. ESR values calculated from initial ohmic drop and found that the ESR value at the $10^{\text {th }}$ cycle was $13 \Omega \cdot \mathrm{cm}^{2}$ which increase to $28 \Omega \cdot \mathrm{cm}^{2}$ after 10,000 cycles. Figure 8 b reports a Ragone plot in which the average energy and power of supercapacitor cells are displayed. The energy and power densities were calculated using equation (5) and (6). Clearly, the SN containing gel electrolyte based solid state supercapacitor cell shows much higher power density compared to pure IL based cell and much higher energy density compared to IL-gel (without SN) based cell. The optimized gel electrolyte (SN-IL-gel-2) based solid-state cell showed maximum power of $24.5 \mathrm{~kW} \mathrm{~kg}^{-1}$ and energy density of $36 \mathrm{Wh} \mathrm{kg}^{-1}$ (at $1.5 \mathrm{~A} \mathrm{~g}^{-1}$ ). Thus, the optimized gel polymer electrolyte cell performance shows the possibility as safe next generation supercapacitors with a high operating voltage, light weight, and simple design. 

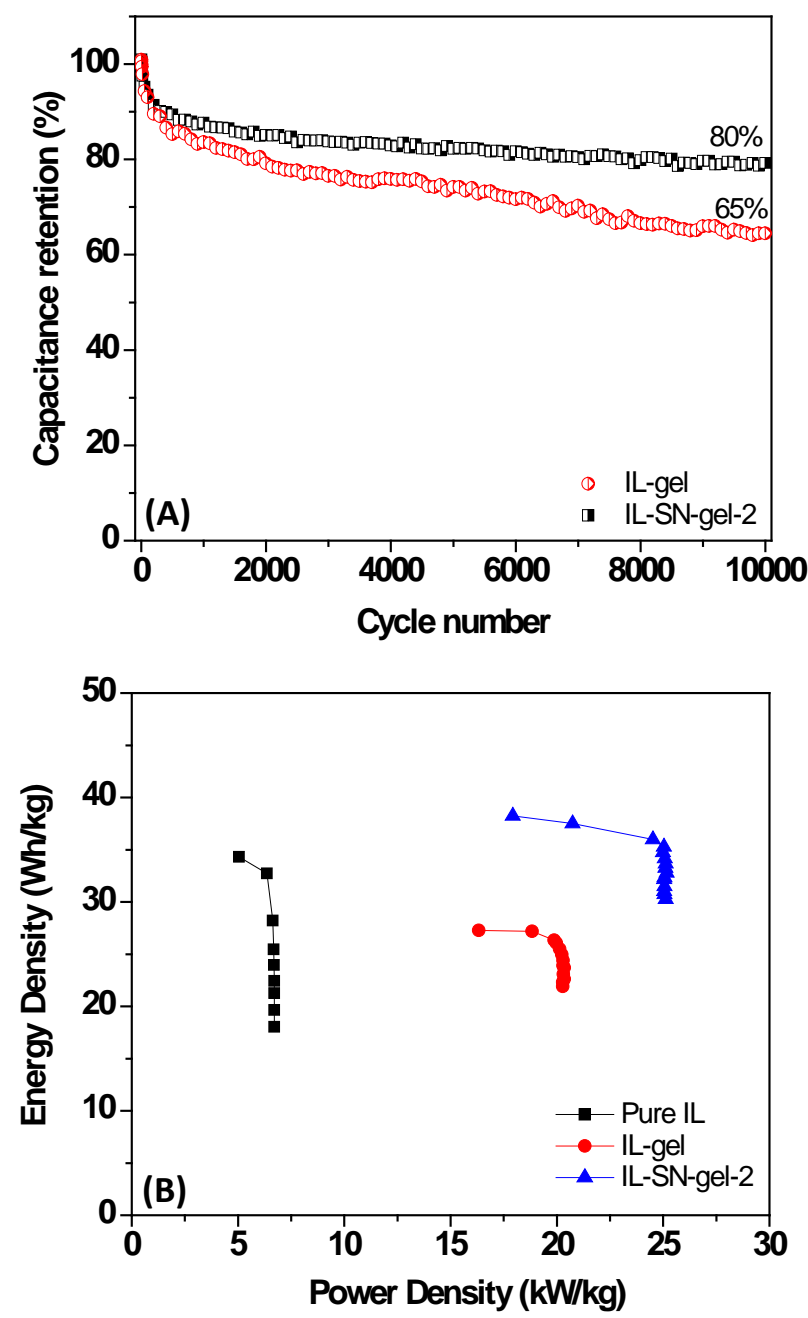

Figure 8: (A) Specific capacitance retention during cycling stability test of EDLCs cells with ILgel and IL-SN-gel-2 electrolytes. The charge-discharge cycling stability test was carried out at constant current density of $1.5 \mathrm{~A} \mathrm{~g}^{-1}$ and device is cycled to $2.5 \mathrm{~V}$.(B) Ragone plot of pure IL, IL-gel and IL-SN-gel-2 electrolyte based EDLCs.

\section{Conclusions}

A thermostable, flexible gel polymer electrolytes based on plastic crystal SN and IL $\left(\mathrm{BMImBF}_{4}\right)$ entrapped in PVdF-HFP matrix is prepared and characterized for its application as both electrolyte and separator in solid-state supercapacitors. The optimized IL/SN based gel polymer electrolyte exhibits a high ionic conductivity $6.40 \times 10^{-3} \mathrm{~S} \mathrm{~cm}^{-1}$ at room temperature and 
widerelectrochemical stability window (-2.9 to $2.5 \mathrm{~V}$ ). DSC studies confirm that the IL/SN based gel polymer electrolyte remainsthermostable over a wide temperature rangefrom -30 to 90 ${ }^{\circ} \mathrm{C}$.Symmetric carbon-carbon solid-state supercapacitor cell with IL/SN based gel polymer electrolyte exhibits higher specific capacitance $176 \mathrm{~F} \mathrm{~g}^{-1}$ at $0.18 \mathrm{~A} \mathrm{~g}^{-1}$ and $138 \mathrm{~F} \mathrm{~g}^{-1}$ at $8 \mathrm{~A} \mathrm{~g}^{-1}$ constant current density. The optimized SN/IL gel polymer electrolytebased solid-state EDLC cell shows maximum power of $24.5 \mathrm{~kW} \mathrm{~kg}^{-1}$ and energy density of $36 \mathrm{Wh} \mathrm{kg}^{-1}$ at $1.5 \mathrm{~A} \mathrm{~g}^{-1}$. When analyzed for long cycling stability, the EDLC cell SN/IL gel polymer electrolyteshows only $20 \%$ decrease in capacitance after 10,000 cycles. The EDLC cell exhibiting decent capacitive behavior over a wide temperature range from -30 to $80{ }^{\circ} \mathrm{C}$. This performance of the device demonstrate that it is possible to design simple lightweight, high operating voltage EDLCs that can replace liquid-based electrolyte systems and improve the safety of the device.

\section{Acknowledgements}

The work at Kansas State University was supported by NSF grant CMMI-1100830, NASA grant NNX13AD42A, NSF EPSCoR Award EPS-0903806, and matching funds provided by the State of Kansas for the latter two.This work was partially funded by NSF grant 1156549.

\section{References}

[1] B.E. Conway, Electrochemical Supercapacitors: Scientific Fundamentals and Technological Applications, Kluwer Academic/Plenum Publisher, New York, 1999.

[2] J.R. Miller, P. Simon, Science 321 (2008) 651-652.

[3] P. Simon, Y. Gogotsi, Nature Materials, 7 (2008) 845-854. 
[4] G.P. Pandey, Y. Fang, J. Li, Advanced materials for supercapacitors, in: P.K. Shen, C.Y.Wang, S.P. Jiang, X. Sun, J. Zhang (Eds.), Electrochemical Energy: Advanced Materials and Technologies, CRC Press, Boca Raton, FL, 2016, pp. 423-449.

[5] A.G. Pandolfo, A.F. Hollenkamp, Journal of Power Sources, 157 (2006) 11-27.

[6] F. Béguin, V. Presser, A. Balducci, E. Frackowiak, Advanced Materials, 26 (2014) 22192251.

[7] A. Lewandowski, M. Zajder, E. Frąckowiak, F. Beguin, Electrochimica Acta, 46 (2001) 2777-2780.

[8] K. Leitner, A. Lerf, M. Winter, J. Besenhard, S. Villar-Rodil, F. Suarez-Garcia, A. MartinezAlonso, J. Tascon, Journal of Power Sources, 153 (2006) 419-423.

[9] G.P. Pandey, S.A. Hashmi, Journal of Power Sources, 243 (2013) 211-218.

[10] D.N. Futaba, K. Hata, T. Yamada, T. Hiraoka, Y. Hayamizu, Y. Kakudate, O. Tanaike, H. Hatori, M. Yumura, S. Iijima, Nature Materials, 5 (2006) 987-994.

[11] M.D. Stoller, S. Park, Y. Zhu, J. An, R.S. Ruoff, Nano Letters, 8 (2008) 3498-3502.

[12] K.L. Van Aken, C.R. Pérez, Y. Oh, M. Beidaghi, Y.J. Jeong, M.F. Islam, Y. Gogotsi, Nano Energy, 15 (2015) 662-669.

[13] V. Presser, J. McDonough, S.-H. Yeon, Y. Gogotsi, Energy \& Environmental Science, 4 (2011) 3059-3066.

[14] T. Sato, S. Marukane, T. Morinaga, T. Kamijo, H. Arafune, Y. Tsujii, Journal of Power Sources, 295 (2015) 108-116.

[15] S. Hashmi, S. Suematsu, K. Naoi, Journal of Power Sources, 137 (2004) 145-151.

[16] G.P. Pandey, S.A. Hashmi, Journal of Materials Chemistry A, 1 (2013) 3372-3378.

[17] S. Yamazaki, A. Takegawa, Y. Kaneko, J.-i. Kadokawa, M. Yamagata, M. Ishikawa, Electrochemistry Communications, 11 (2009) 68-70. 
[18] G.P. Pandey, A.C. Rastogi, C.R. Westgate, Journal of Power Sources, 245 (2014) 857-865.

[19] L. Negre, B. Daffos, P. Taberna, P. Simon, Journal of The Electrochemical Society, 162 (2015) A5037-A5040.

[20] W. Lu, K. Henry, C. Turchi, J. Pellegrino, Journal of the Electrochemical Society, 155 (2008) A361-A367.

[21] Y. Kumar, G.P. Pandey, S.A. Hashmi, The Journal of Physical Chemistry C, 116 (2012) 26118-26127.

[22] Y.J. Kang, H. Chung, C.-H. Han, W. Kim, Nanotechnology, 23 (2012) 065401.

[23] A.S. Westover, J.W. Tian, S. Bernath, L. Oakes, R. Edwards, F.N. Shabab, S. Chatterjee, A.V. Anilkumar, C.L. Pint, Nano letters, 14 (2014) 3197-3202.

[24] L. Negre, B. Daffos, V. Turq, P.L. Taberna, P. Simon, Electrochimica Acta, (2016) doi:10.1016/j.electacta.2016.1002.1013.

[25] L.-Z. Fan, J. Maier, Electrochemistry communications, 8 (2006) 1753-1756.

[26] K.-H. Choi, S.-H. Kim, H.-J. Ha, E.-H. Kil, C.K. Lee, S.B. Lee, J.K. Shim, S.-Y. Lee, Journal of Materials Chemistry A, 1 (2013) 5224-5231.

[27] Z. Chen, H. Yang, X. Li, F. Li, T. Yi, C. Huang, Journal of Materials Chemistry, 17 (2007) 1602-1607.

[28] P.-J. Alarco, Y. Abu-Lebdeh, A. Abouimrane, M. Armand, Nature materials, 3 (2004) 476481.

[29] D.R. MacFarlane, M. Forsyth, Advanced materials, 13 (2001) 957-966.

[30] K. Liu, F. Ding, Q. Lu, J. Liu, Q. Zhang, X. Liu, Q. Xu, Solid State Ionics, 289 (2016) 1-8.

[31] M. Suleman, Y. Kumar, S. Hashmi, Journal of Solid State Electrochemistry, 19 (2015) 1347-1357.

[32] J. Fan, P.S. Fedkiw, Journal of the Electrochemical Society, 144 (1997) 399-408. 
[33] G.P. Pandey, S.A. Hashmi, Journal of Power Sources, 187 (2009) 627-634.

[34] D. Bamford, A. Reiche, G. Dlubek, F. Alloin, J.-Y. Sanchez, M.A. Alam, The Journal of chemical physics, 118 (2003) 9420-9432.

[35] M. Yamagata, K. Soeda, S. Yamazaki, M. Ishikawa, Electrochemical and Solid-State Letters, 14 (2011) A165-A169.

[36] J. Jacquemin, P. Husson, A.A.H. Padua, V. Majer, Green Chemistry, 8 (2006) 172-180.

[37] M. Yamagata, K. Soeda, S. Ikebe, S. Yamazaki, M. Ishikawa, Electrochimica Acta, 100 (2013) 275-280.

[38] M. Schroeder, P. Isken, M. Winter, S. Passerini, A. Lex-Balducci, A. Balducci, Journal of The Electrochemical Society, 160 (2013) A1753-A1758.

[39] K. Soeda, M. Yamagata, M. Ishikawa, Journal of Power Sources, 280 (2015) 565-572.

[40] G.A. Tiruye, D. Muñoz-Torrero, J. Palma, M. Anderson, R. Marcilla, Journal of Power Sources, 279 (2015) 472-480.

[41] P. Taberna, P. Simon, J.-F. Fauvarque, Journal of the Electrochemical Society, 150 (2003) A292-A300.

[42] R. Hastak, P. Sivaraman, D. Potphode, K. Shashidhara, A. Samui, Journal of Solid State Electrochemistry, 16 (2012) 3215-3226.

[43] D. Bélanger, X. Ren, J. Davey, F. Uribe, S. Gottesfeld, Journal of the Electrochemical Society, 147 (2000) 2923-2929.

[44] C. Schütter, C. Ramirez-Castro, M. Oljaca, S. Passerini, M. Winter, A. Balducci, Journal of The Electrochemical Society, 162 (2015) A44-A51.

[45] A.A. Łatoszyńska, G.Z. Żukowska, I.A. Rutkowska, P.-L. Taberna, P. Simon, P.J. Kulesza, W. Wieczorek, Journal of Power Sources, 274 (2015) 1147-1154. 
[46] R. Yi, S. Chen, J. Song, M.L. Gordin, A. Manivannan, D. Wang, Advanced Functional Materials, 24 (2014) 7433-7439. 
Table 1: Room temperature ionic conductivity of IL and succinonitrile basedgel polymer electrolytes

\begin{tabular}{lll}
\hline Electrolytes & & Conductivity $\left(\mathbf{S ~ c m}^{-1}\right)$ \\
\hline Pure IL & $\left(\mathrm{BMImBF}_{4}\right)$ & $4.03 \times 10^{-3}$ \\
\hline IL-gel & $(\mathrm{PVdF}-H F P / I L / S N ; 1: 4: 0, \mathrm{w} / \mathrm{w} / \mathrm{w})$ & $1.79 \times 10^{-3}$ \\
\hline IL-SN-gel-1 & $(\mathrm{PVDF}-H F P / I L / S N ; 1: 3: 1, \mathrm{w} / \mathrm{w} / \mathrm{w})$ & $5.14 \times 10^{-3}$ \\
\hline IL-SN-gel-2 & $(\mathrm{PVDF}-H F P / I L / S N ; 1: 2: 2, \mathrm{w} / \mathrm{w} / \mathrm{w})$ & $6.40 \times 10^{-3}$ \\
\hline IL-SN-gel-3 & $(\mathrm{PVDF}-H F P / I L / S N ; 1: 1: 3, \mathrm{w} / \mathrm{w} / \mathrm{w})$ & $3.50 \times 10^{-3}$ \\
\hline
\end{tabular}


Table 2: Comparison of electrochemical performance of supercapacitor cells with different composition of gel electrolytes and pure IL using EIS.

\begin{tabular}{|c|c|c|c|}
\hline Electrolytes & $\begin{array}{c}\text { ESR } \\
\left(\Omega \cdot \mathbf{c m}^{2}\right)\end{array}$ & $\begin{array}{c}\mathrm{C}_{0} \text { at } 1 \mathrm{mHz} \\
\left(\mathrm{F} \mathrm{g} \mathrm{g}^{-1}\right)\end{array}$ & Time constant \\
\hline Pure IL & 31.4 & 105 & $40 \mathrm{~s}$ \\
\hline IL-gel & 7.6 & 99 & $6.6 \mathrm{~s}$ \\
\hline IL-SN-gel-1 & 11.6 & 110 & $10.6 \mathrm{~s}$ \\
\hline IL-SN-gel-2 & 9.8 & 126 & $11.0 \mathrm{~s}$ \\
\hline IL-SN-gel-3 & 7.6 & 90 & $5.5 \mathrm{~s}$ \\
\hline
\end{tabular}


Table 3: Mass specific capacitance, areal capacitance (calculated from EIS data at $10 \mathrm{mHz}$ ) and ESR values obtained at different temperature for a typical supercapacitor cell with IL-SN-gel-2 electrolyte.

\begin{tabular}{|c|c|c|c|}
\hline $\begin{array}{l}\text { Temperature } \\
\left({ }^{\circ} \mathrm{C}\right)\end{array}$ & $\begin{array}{l}\text { Specific capacitance } \\
\qquad\left(F g^{-1}\right)\end{array}$ & $\begin{array}{l}\text { Areal capacitance } \\
\qquad\left(\mathrm{mF} \mathrm{cm}^{-2}\right)\end{array}$ & $\begin{array}{c}\text { ESR } \\
\left(\Omega \cdot \mathbf{c m}^{2}\right)\end{array}$ \\
\hline-30 & 91 & 160 & 50.4 \\
\hline-20 & 100 & 175 & 29.4 \\
\hline 0 & 103 & 180 & 19.6 \\
\hline RT & 110 & 192 & 13.1 \\
\hline 40 & 113 & 198 & 16.8 \\
\hline 80 & 116 & 203 & 23.8 \\
\hline
\end{tabular}




\section{Graphical Abstract}
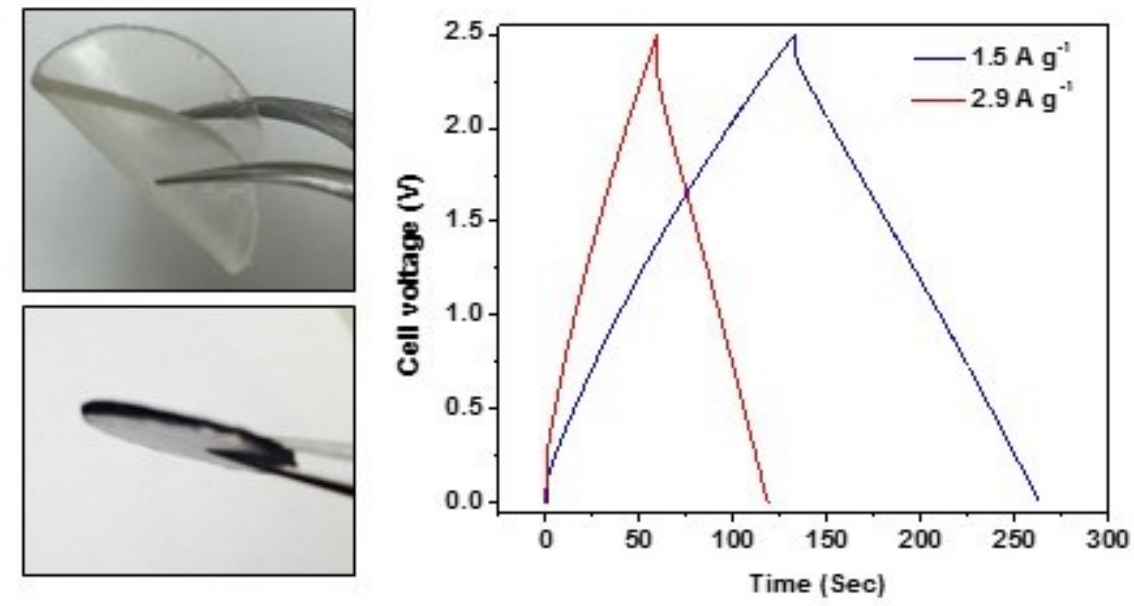